\title{
Toxicity of Heavy Metals and Microbial Analysis of Soil Samples Collected from the Area around Zliten Cement Factory
}

\author{
Abdulmajeed Bashir Mlitan ${ }^{1 *}$, Adel Imhemed Alajtal ${ }^{2}$, Abdullah Mohamed Alsadawy ${ }^{1}$ \\ ${ }^{1}$ Department of Biology, Faculty of Science, University of Misurata, Misurata, Libya \\ ${ }^{2}$ Department of Chemistry, Faculty of Science, University of Misurata, Misurata, Libya \\ Email:"aefmsr2012@yahoo.com
}

Received December 21, 2012; revised January 25, 2013; accepted February 4, 2013

\begin{abstract}
Soil samples were collected from and around Zliten cement factory, Zliten town, Libya. Soil metals and microbial contents were determined. The results obtained for the examined physiochemical characteristics of soil in the area studied prove that cement dust from the Zliten cement factory in Libya has had a significant impact on the soil. The affected soil properties are $\mathrm{pH}$ and total calcium content. These characteristics were found to be higher than those in similar soils from the same area (unpolluted). The increment of soil $\mathrm{pH}$ in the same area may be a result of precipitation of cement dust over the years. Metal uptake from cement to plants and soil then affects organisms' bodies, a fact that seems to be reflected in this study. Different responses were found in each site. For instance, the dominance of fungi of soil was lowest at $100 \mathrm{~m}$ from the factory and the evenness and diversity increased at this site compared to $300 \mathrm{~m}$ from the factory and the control area.
\end{abstract}

Keywords: Pollution; Soil Microbial; Heavy Metals; Zliten-Libya

\section{Introduction}

The problem of environmental pollution due to toxic metals is of major concern in most major metropolitan cities. The toxic metals entering the ecosystem may lead to geoaccumulation, bioaccumulation and biomagnifications. Whereas trace metals are necessary for proper functioning of biological systems, their deficiency or excess can lead to a number of disorders [1].

Heavy metals occur naturally in the soil environment from the pedogenetic processes of weathering of parent materials at levels that are regarded as trace $(<1000$ $\left.\mathrm{mg} \cdot \mathrm{kg}^{-1}\right)$ and rarely toxic [2,3]. Due to the disturbance and acceleration of nature's slowly occurring geochemical cycle of metals by man, most soils of rural and urban environments may accumulate one or more of the heavy metals above defined background values high enough to cause risks to human health, plants, animals, ecosystems, or other media [4].

Cement withdraws an attention as a pollutant. The raw materials of the cement have mainly the following constituents: $75 \%$ limestone $\left(\mathrm{CaCO}_{3}\right) ; 20 \%$ - $25 \%$ clay $\left(\mathrm{Al}_{2} \mathrm{O}_{3}+\mathrm{Fe}_{2} \mathrm{O}_{3}\right) ; 5 \%$ sand $\left(\mathrm{SiO}_{2}\right)$ and $2 \%$ Ferric oxide $\left(\mathrm{Fe}_{2} \mathrm{O}_{3}\right)$. In fact cements are mineral materials, basically hydrated silicate and portlandite $\left[\mathrm{Ca}\left(\mathrm{OH}_{2}\right)_{2}\right]$ for the ordi-

"Corresponding author. nary Portland cement [5]. Cement adversely affects the populations of microorganisms.

Air pollutants, responsible for vegetation injury and crop yield losses, are causing increased concern [6]. Air pollution has become a major threat to the survival of plants in the industrial areas [7]. Rapid industrialization and addition of the toxic substances to the environment are responsible for altering the ecosystem [8-10].

Changes in soil properties have been associated with environmental alteration that takes place, for example as a result of human activity [11]. As soon as cement contacts the soil surface its constituents enter inside the earth. Its metal constituents undergo several reactions which can affect soil including its chemical and physical characteristics [11]. As cement has high carbonate content, the dust tends to be highly alkaline. Therefore, it is likely that soil contaminated by cement will have high $\mathrm{pH}$. The biological, physical and chemical properties of soil, such as water content, electrical conductivity, and $\mathrm{pH}$, were all found to be affected when treated by raw materials of cement [12].

A large number of studies have investigated fungi isolated from acidic to neutral soils. However, relatively few have investigated fungi in alkaline soils. Soils with high concentrations of calcium carbonate or exposed to 
cement dust were studied by [13-16]. In these studies the most common fungi were Aspergillus, Cladosporium, Gliocladium, Mucor, Penicillium, Trichoderma, Acremonium species and two Chrysosporium species. Almost of these fungi grew well in alkaline conditions.

The relationships among soil properties, fungi, and cement dust as a pollutant have been explored in relatively few studies. Many studies $[14,17,18]$ isolated fungi from soil exposed to cement, but did not focus on the effects of cement on fungal characteristics such as protein or enzyme content or pigmentation products, nor did they present a particular reason why such effects occur.

The aim of this study was to investigate the effect on soil of cement dust emitted the area around Zliten cement factory. Genera of fungi which are present in soil microflora in the area contaminated by cement were investigated, as well as $\mathrm{pH}$, moisture, and heavy metals content in the polluted soil, comparing the findings with those for soil samples taken from an unpolluted area.

\section{Materials and Methods}

Zliten cement factory is located in Zliten town which is situated $160 \mathrm{~km}$ east of the capital, Tripoli, and about 35 $\mathrm{km}$ east of the ancient Roman city of Leptis Magna. It is about $60 \mathrm{~km}$ west of the city of Misurata.

Soil samples were collected from four different sites A (inside the factory), B (100 m from the factory), C (300 $\mathrm{m}$ from the factory) and D $100 \mathrm{~km}$ away in the area of Misurata for the control, to investigate microfungi, heavy metals, $\mathrm{pH}$ and water content of unpolluted soil (control) and soil that had been continually exposed to cement dust. at depth of $1-10 \mathrm{~cm}$ and three samples from each site, Sampling distances of $100 \mathrm{~m}$ and $300 \mathrm{~m}$ for polluted soil were selected due to some physicochemical characteristics variations such as $\mathrm{pH}$, content of elements, moisture and salinity of their soil according to results not published in the same area (Alkomos cement factory) in Libya [19] and published results in Turkey (Edremit cement factory) [13]. The collection sites for contaminated soil were to the east of the cement plant because of prevailing winds from the west. In these locations the view is not clear, particularly in summer, and the probability of dust deposits is larger than at any other direction around cement the factory. It should be noted that site 1, $100 \mathrm{~m}$ from the cement factory, is located on a small hill. The distance between stations at the same site was $10 \mathrm{~m}$ and soil was collected from 5 to $15 \mathrm{~cm}$ depth.

Soil texture, organic matter, total soluble salts, water content and $\mathrm{pH}$ value were determined according to the method described by Chaturvedi and Sankar [20]. The soil metals were determined according to reference number [21]. Total numbers of fungi per gram of soil were counted by using the dilution plate method for each type of soil samples as described by Biyik [13] using Sabou- raud medium and Czapek medium. All mentioned experiments were taken place on soil samples far away from unpolluted area as comparison.

The $\mathrm{pH}$ was measured with $\mathrm{pH}$ meter. The $\mathrm{pH}$ meter was calibrated with buffer solutions at $\mathrm{pH} 4,7$ and 9 . Metals were determined according to the standard methods of AOAC [21] by Atomic Absorption Spectrophotometer (180-30 Hitachi).

\section{Results and Discussion}

The results obtained from the field work examining some physicochemical characteristics of soils from and around Zliten cement factory have indicated a strong influence by this factory dusts that have settled on the soil from the cement factory. It can be concluded that the effect of dust on soil metals content, water content and $\mathrm{pH}$ of soil depended not only on period of exposure to this dust. Results of soil analysis are shown in Table 1.

The organic matter was low in soil samples and they ranged from 0.11 to $0.25 \mathrm{~g}$, the $\mathrm{pH}$ values of the soil samples revealed no significant differences at all localities, $\mathrm{pH}$ values ranged from 8.46 to 8.68 . Since all samples contained very low amounts of organic matter, this result is consistent with other finding of earlier studieson Libyan soils [22,23]. Also water content ranged from $2.06 \%$ to $4.17 \%$.

The concentrations of metals in the samples analysed are reported in Table 2. The results show that the soil samples from different localities differ in their metals content and the metal concentrations inside the factory samples were higher than others. All tested metals $(\mathrm{Cd}$, $\mathrm{Pb}, \mathrm{Al}, \mathrm{Cu}$ and $\mathrm{Ca}$ ) except $\mathrm{Ca}$ contained the highest amounts in the first location (inside the factory). There were significant differences in soil metals content between first location (inside factory) and unpolluted samples $(P<0.001)$. Pollution of soil by heavy metals occurs due to different sources such as industrial wastes, application of fertilizers, corrosion of sheeting, wires, pipes, burning of coal and wood, and fuel hydrocarbons. Soil heavy metals content from different places of the world

Table 1. pH value, organic matter and water content of different locations from the cement factory. Sites $A$ (inside the factory), B (100 $\mathrm{m}$ from the factory), C (300 $\mathrm{m}$ from the factory) and $D 100 \mathrm{~km}$ away in the area of misurata for the control.

\begin{tabular}{cccc}
\hline Locations & $\mathrm{pH}$ & $\begin{array}{c}\text { Organic } \\
\text { matter }(\mathrm{g})\end{array}$ & $\begin{array}{c}\text { Water content } \\
(\%)\end{array}$ \\
\hline $\mathrm{A}$ & 8.55 & 0.25 & 4.17 \\
$\mathrm{~B}$ & 8.68 & 0.11 & 2.31 \\
$\mathrm{C}$ & 8.55 & 0.13 & 2.94 \\
$\mathrm{D}$ & 8.46 & 0.17 & 2.06 \\
\hline
\end{tabular}


Table 2. Concentration (ppm) of calcium (Ca), copper (Cu), cadmium (Cd), lead (Pb) and aluminium (Al) in different localities from the cement factory. Sites $A$ (inside the factory), B (100 $\mathrm{m}$ from the factory), C (300 $\mathrm{m}$ from the factory) and $D 100 \mathrm{~km}$ away in the area of misurata for the control.

\begin{tabular}{cccccc}
\hline Locations & $\mathrm{Ca}$ & $\mathrm{Cu}$ & $\mathrm{Cd}$ & $\mathrm{Pb}$ & $\mathrm{Al}$ \\
\hline \multirow{2}{*}{$\mathrm{A}$} & \pm 0.01 & \pm 0.11 & \pm 0.14 & \pm 0.28 & \pm 0.23 \\
& 167.40 & 0.36 & 0.19 & 0.18 & 6.33 \\
& \pm 0.12 & \pm 0.01 & \pm 0.16 & \pm 0.18 & \pm 0.09 \\
$\mathrm{~B}$ & 142.00 & 0.06 & 0.12 & 0.09 & 2.98 \\
& \pm 0.02 & \pm 0.08 & \pm 0.01 & \pm 0.03 & \pm 0.12 \\
$\mathrm{C}$ & 145.30 & 0.08 & 0.18 & 0.03 & 3.25 \\
& \pm 0.22 & \pm 0.02 & \pm 0.23 & \pm 0.04 & \pm 0.01 \\
$\mathrm{D}$ & 160.26 & 0.16 & 0.06 & 0.02 & 3.02 \\
\hline
\end{tabular}

Table 3. Fungal flora (colonies number) isolated from different localities from the cement factory using sabouraud medium. Sites A (inside the factory), B (100 $\mathrm{m}$ from the factory), $C$ (300 $\mathrm{m}$ from the factory) and $D 100 \mathrm{~km}$ away in the area of misurata for the control.

\begin{tabular}{ccccc}
\hline Fungal name & A & B & C & D \\
\hline Rhizopus sp & 2 & 1 & 1 & - \\
Aspergillus sp1 & 5 & 1 & - & - \\
Aspergillus sp2 & 5 & 2 & 5 & 1 \\
Aspergillus sp3 & 3 & 4 & - & - \\
Aspergillus sp4 & 3 & 1 & 13 & - \\
Aspergillus ochraceus & 2 & 1 & 5 & - \\
Aspergillus niger & 2 & 1 & 4 & - \\
Fusarium sp & 10 & 8 & 14 & 1 \\
Total colonies & 32 & 19 & 42 & 2 \\
Total species & 8 & 8 & 6 & 2 \\
Total genus & 3 & 3 & 3 & 2 \\
\hline
\end{tabular}

are well known [25-30], while no studied concerning metal and microbial analysis in Zliten-Libya.

The total number of fungal soil colonies per gram of soil is shown in Table 3. Different soil localities support the growth of three fungal genera in Tables $\mathbf{3}$ and $\mathbf{4}$.

The fungal genera are Aspergillus, Rhizopus and Fusarium isolated in the present study, such genera were previously reported in different soils polluted by cement [13, 19,31] Aspergillus having the greatest diversity of fungal species in soil polluted by cement, [31] and [17] observed the same trend for Aspergillus compared to other fungal species.

The effect of organic matter, total soluble salts, $\mathrm{pH}$ value, and metals on soil microbial flora are severally different from place to another. Overall, heavy metals were generally toxic to soil microbial flora, but some
Table 4. Fungal flora (colonies number) isolated from different localities using Czapek medium from the cement factory. Sites A (inside the factory), B (100 $\mathrm{m}$ from the factory), $C$ (300 $\mathrm{m}$ from the factory) and $D 100 \mathrm{~km}$ away in the area of misurata for the control.

\begin{tabular}{ccccc}
\hline Fungal name & $\mathrm{A}$ & $\mathrm{B}$ & $\mathrm{C}$ & $\mathrm{D}$ \\
\hline Aspergillus $\mathrm{sp}_{1}$ & 8 & 4 & - & - \\
Aspergillus $\mathrm{sp}_{2}$ & 8 & - & - & - \\
Aspergillus niger & 4 & 3 & 5 & - \\
Aspergillus ochrace & 6 & 2 & 9 & - \\
Fusarium sp & 2 & 10 & 28 & 2 \\
Rhizopus sp & 10 & 10 & 12 & - \\
Total colonies & 38 & 29 & 54 & 2 \\
Total species & 6 & 5 & 4 & 1 \\
Total genus & 3 & 3 & 3 & 1 \\
\hline
\end{tabular}

microorganims appeared to benefit from some concentrations [24].

\section{Conclusion}

As per the results obtained, it is concluded that the physicochemical characteristics of soils $(\mathrm{pH}$, water content, organic matter) in the study area indicate a strong influence by cement dusts that have settled on the soil from the factory. Metals determined in polluted soil indicated high concentrations in first site (inside cement factory). The reduction of fungal colonies in polluted soil by cement may attribute to higher metals and $\mathrm{pH}$.

\section{REFERENCES}

[1] N. I. Ward, "Environmental Analytical Chemistry," In: F. W. Fifield and P. J. Haines, Eds., Trace Elements, Blackie Academic and Professional, 1995, pp. 320-328.

[2] A. Kabata-Pendias and H. Pendias, "Trace Metals in Soils and Plants," 2nd Edition, CRC Press, Boca Raton, 2001.

[3] G. M. Pierzynski, J. T. Sims and G. F. Vance, "Soils and Environmental Quality," 2nd Edition, CRC Press, London, 2000 .

[4] J. J. D. Amore, S. R. Al-Abed, K. G. Scheckel and J. A. Ryan, "Methods for Speciation of Metals in Soils: A Review," Journal of Environmental Quality, Vol. 34, No. 5, 2005, pp. 1707-1745. doi:10.2134/jeq2004.0014

[5] J. V. Perfettini, E. Revertegatand and N. Langomazino, "Evaluation of Cement Degradation Induced by the Metabolic Products of Two Fungal Strains," Experientia, Vol. 47, No. 6, 1991, pp. 527-33. doi:10.1007/BF01949872

[6] S. Fuji, "The Current State of Plant Damage by Air Pollution in Okayama Perfecture," Shokbutsu Boeki, Vol. 27, 1973, pp. 249-252.

[7] A. K. Gupta and R. M. Mishra, "Effect of Lime kilnÕs 
Air Pollution on Some Plant Species," Pollution Research, Vol. 3, No. 1, 1994, pp. 1-9.

[8] J. B. Mudd and T. T. Kozlowski, "Response of Plants to Air Pollution," Academic Press, New York, 1975, p. 383.

[9] J. O. Niragau and C. I. Davidson, "Toxic Metals in the Atmosphere," Jon Wiley and Sons, New York, 1986.

[10] G. D. Clayton and F. E. Clayton, "Pattys Industrial Hygiene and Technology," Wiley Interscience, New York, 1982.

[11] I. J. Ibanga, N. B. Umoh and O. B. Iren, "Effects of Cement Dust on Soil Chemical Properties in the Calabar Environment, Southeastern Nigeria," Communications in Soil Science and Plant Analysis, Vol. 39, No. 3-4, 2008, pp. 551-558. doi:10.1080/00103620701826829

[12] M. R. Khan and M. W. Khan, "The Effect of Fly Ash on Plant Growth and Yield of Tomato," Environmental Pollution, Vol. 92, 1996, pp. 105-111. doi:10.1016/0269-7491(95)00098-4

[13] H. Biyik, A. Imali, E. Atalan, S. Tufenkci and E. Ogun, "Diversity of Microfungi in Soil Polluted by Cement Factory," Fresenius Environmental Bulletin, Vol. 14, No. 15, 2005, pp. 130-137.

[14] S. K. Hemida, M. M. K. Bagy and A. M. A. Khallil, "Fungal Flora of Cement Polluted Soils in Egypt," Zentralblatt Fur Mikrobiologie, Vol. 148, No. 2, 1993, pp. 148-157.

[15] E. Vardavakis, "Seasonal Fluctuations of Soil Microfungi in Correlation with Some Soil Enzyme Activities and VA Mycorrhizae Associated with Certain Plants of a Typical Calcixeroll Soil in Greece," Mycologia, Vol. 82, No. 6, 1990, pp. 715-726. doi:10.2307/3760158

[16] K. Nagai, T. Sakai, R. M. Rantiatmodjo, K. Suzuki, W. Gams and G. Okada, "Studies on the Distribution of Alkalophilic and Alkali-Tolerant Soil Fungi," Mycoscience, Vol. 36, No. 3, 1995, pp. 247-256. doi:10.1007/BF02268598

[17] S. K. Hemida, "Fungal and Bacterial Populations in Cement-Incorporated Soil," International Journal of Agriculture \& Biology, Vol. 7, No. 2, 2005, pp. 158-161.

[18] İ. Ocak, Y. Sülün and İ. Hasenekoğlu, "The Effect of Cement Dust Emitted from Gaziantep Cement Plant on Microfungus Flora of Surroundings Soils," Trakya University Journal of Science, Vol. 5, No. 2, 2004, pp. 107-115.
[19] A. B. Mlitan, "Some Physical and Environment Studies for the Effect of Pollution with the Dust of Cement on Fungi, Biology," Msc Thesis, Misurata University, Misurata-Libya, 2000.

[20] R. K. Chetutvedi and K. Sankar, "Laboratory Manual for the Physico-Chemical Analysis of Soil, Water and Plant," Wildlife Institute of India, Dehradum, 2006.

[21] AOAC, "Ocial, Methods of Analysis," 14th Edition, Washington DC, 1984.

[22] S. Alarabi and M. Alsol, "The Effect of Cement Dust Pollution on the Olea europaea and Nicotiana glauca Inthe Area between Misurate and Alkomos in Libya," Msc Thesis, Nasir University, Misurate-Libya, 1998.

[23] S. Hmad, A. Alwerfaly, A. Zerek, M. El Soul and A. Mlitan, "Cement, Manfacturing Impact on the Prunus and Ficus Trees in Margeb Region of Libya," The Third International Conference for Development and Environment in the Arab World, The Centre of Environment Researches in Egypt, Assiut, 2006, pp. 12-17.

[24] I. S. Ross, "Effect of Heavy Metals on the Microbial Growth," Transactions of the British Mycological Society, Vol. 78, No. 3, 1982, pp. 543-533. doi:10.1016/S0007-1536(82)80165-4

[25] H. L. Ehrlich, "Geomicrobiology," Marcel Dekker, Inc., New York

[26] A. Andersson, "Heavy Metals on Swedish Soils," Swedish Journal of Agricultural Research, Vol. 7, 1981, pp. 720.

[27] H. Bown, "Soil Pollution," Education Chemistry, Vol. 12, 1975, pp. 72-74.

[28] M. Dudas and S. Dowluk, "Heavy Metals in Cultivated Soils," Canadian Journal of Soil Science, Vol. 57, No. 3, 1977, pp. 329-339. doi:10.4141/cjss77-037

[29] K. Pendias and A. Pendias, "Trace Elements in Soils and Plants," CRC Press, New York, 1985.

[30] B. E. Davies, “Applied Soil Trace Elements,” John Wiley and Sons, New York, 1980.

[31] M. M. K. Bagy and S. K. Hemida, "Air Spora and Leaf Surface Fungi of Three Plants, Exposed to Cement Dust, in Assiut, Egypt," A Bulletin of the Faculty of Science, Vol. 21, No. 1, 1992, pp. 117-132. 